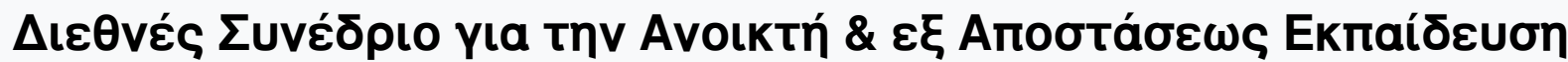

Tóp. 5, Ap. 3B (2009)

Open and Distance Education for Global Collaboration \& Educational Development

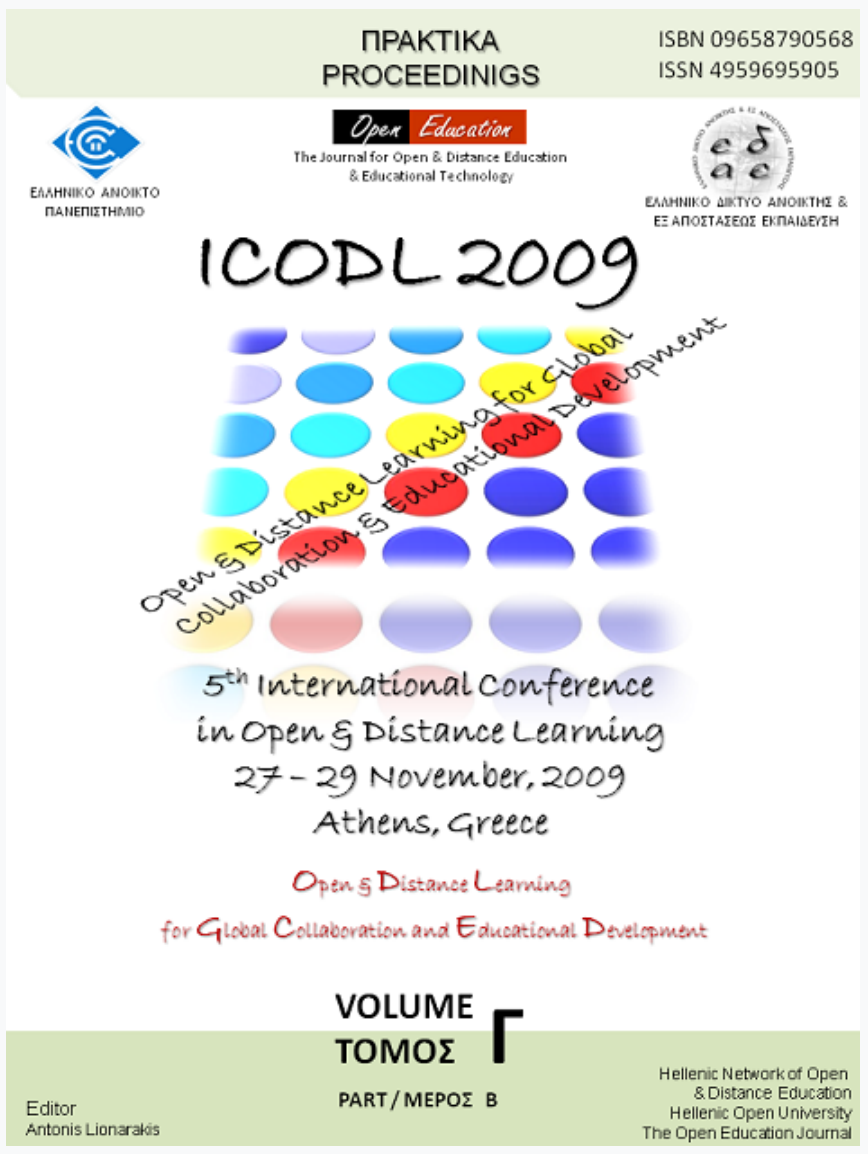

Training as exchange and negotiation of knowledge: online and in presence experiences

Paola NICOLINI, Tamara LAPUCCI

doi: $10.12681 /$ icodl. 457 


\title{
Training as exchange and negotiation of knowledge: online and in presence experiences
}

Paola NICOLINI

Department of Educational and Training Sciences Macerata University (Italy)

Associate Professor

nicolini@unimc.it

\section{Tamara LAPUCCI}

Department of Educational and Training Sciences

Macerata University (Italy)

PhD student

t.lapucci@unimc.it

\begin{abstract}
To provide evidences of the efficacy of e-training, we will show the learning achievements obtained within two different courses, both offered in traditional and online contexts at the University of Macerata (Italy). We intend to deal with the Training to Communication Workshop (TCW) and the Workshop for Observing Children at School (WOCS), providing the theoretical assumptions, the learning design and the analysis of the outcomes.
\end{abstract}

\section{Introduction}

According to the objectivist point of view, in training processes teachers plan the useful path to let the students reach one or more established goals. Objectivists support the idea that "knowledge consists in correctly conceptualizing and categorizing things in the world and grasping the objective connection among those things and those categories" (Lakoff, 1987, p. 163). There is only one correct possibility to reach this correspondence and only one correct understanding of any topic (Vrasidas, 2000). As students are asked to achieve the relation between abstract symbols and real world, the evaluation is goal-driven (Jonassen, 1992). The assessment is mainly based on learners products and they are mostly similar to a paper and pencil test (Bennet, 1998). The students themselves can compare their answers to the correct model, so that to conduct an auto-evaluation is a quite easy task. There are also software able to offer this kind of control and feedback (Rafaeli and Tractinsky, 1989; 1991; Rafaeli, Barak, Dan-Gur and Toch, 2003).

In a constructivist perspective the structure of the world is mainly created by the human mind (Piaget, 1970), so that knowledge is mostly an interpretive process (Kuhn, 1996).Within this theoretical framework training is a more complex process. On the hand of trainees, it has to be considered a continuous re-organization of previous interpretations or a progressive conceptual change (Mason, 2001). The contents of a training course have to be translated into individual competence, which permits the trainees to adequately apply and creatively use their achievements (Gardner, 1991). Furthermore, in socio-constructivist approaches, knowledge is considered the result of construction of meaning and negotiation that happens within social exchanges (Bruner, 1990), so that teaching is not just a simple transfer of information, but an active building of data and understanding, situated within authentic relationships and real discursive interactions (Gee and Green, 1998; Doise and Mugny, 1981). Evaluation through pen and pencil tests is clearly not sufficient (Lesh and Doerr, 2003; Sternberg 1997). Constructivist teachers offer goal-free activities and allow learners have an active role in the evaluation process (Jonassen, 
1992b), to facilitate metacognitive process on the work (Lake and Tessner; 1997; Posner, 1995; Vrasidas, 2000). In this way the traditional central role of teacher clearly decreases.

Also in online courses the teacher role turns moreover in offering authentic activities, letting the group of students interacting and reaching possible solutions to given problems. The expert is not yet used as a model or as a dispenser of information, but more often to provide an adequate learning design and scaffolding (Perkins, 1992). This is the reason why online courses can work in the same way or even better than the in presence one. In fact, in distance education it is difficult to have immediate teacher feedback like it can happen within in presence courses. Peer to peer review is enhanced through the use of specific tools like forum or collaborative writing (Pear and Chrone-Todd, 2002). Also the assessment can be carried on by the students themselves, if they are provided with the useful criteria.

We intend to offer evidences of this topic, dealing with two different training courses offered both in traditional and at distance modality, using the same format.

\section{The structure of the courses: the Training to Communication Workshop (TCW) and the Workshop for Observing Children at School (WOCS)}

We followed a socio-constructivist framework to organize two different courses: the TCW and the WOCS. They are both part of the curriculum in Primary Education Sciences Course at the University of Macerata. The Workshops are addressed to subjects who will be teachers in their professional life. TCW is offered to the students in the first year; WOCS is inserted in the final year of the curriculum. The Workshops are organized in traditional and online modality, according to the same teachinglearning design. It means that the participants to face-to face lessons of TCW did the same activities of their online colleagues, even if using different tools. The same happens for the students of WOCS.

In this paper we will present the adopted choices and the different obtained results. The contribution is organized as follows: in the further section we will outline the characteristic and the activities of both the Workshops, underlining the specific tools used in online and in presence modality. In section 3 variations of the considered Workshops will be illustrated. Section 4 will provide and discuss some data about the outcomes. In the final part we will draw some general conclusions.

\section{The Training to Communication Workshop (TCW)}

TCW proposes activities finalized to study and analyze teaching-learning interactions. In particular the course stresses the importance of negotiation as a method for problem solving. The online Workshop is structured into 9 activities, both subjective and collective. The in presence course follows the same structure of activities along 2 months, in 7 meetings of 3 hours each.

\begin{tabular}{|l|l|l|}
\hline Date & Activity & Aim \\
\hline $\begin{array}{l}17-23 \\
\text { Nov }\end{array}$ & $\begin{array}{l}\text { Read the didactic contract and the list of activities and deadlines. Fill the presentation form } \\
\text { Write down your idea of "communication”, "conflict", "negotiation”. It's not required a } \\
\text { scientific definition, we would like to know your personal conception built through your } \\
\text { experience }\end{array}$ & $\begin{array}{l}\text { Eliciting self explanation and } \\
\text { using naïve theories }\end{array}$ \\
\hline $\begin{array}{l}24 \mathrm{Nov} \\
3 \mathrm{Dec}\end{array}$ & $\begin{array}{l}\text { Read the available text. It is a transcription of part of a real teacher-pupil interaction in class. } \\
\text { Individually find weaknesses and strengthens in the communicative exchange and then try } \\
\text { to improve it. Publish your work. }\end{array}$ & $\begin{array}{l}\text { Eliciting self explanation and } \\
\text { using naïve theories }\end{array}$ \\
\hline
\end{tabular}




\begin{tabular}{|c|c|c|}
\hline 4-18 Dec & $\begin{array}{l}1{ }^{\text {st }} \text { web forum: read the works done by your colleagues. Within your own group discuss and } \\
\text { negotiate a shared file about weaknesses and strengthens of the interaction, proposing } \\
\text { further strategies to improve it. }\end{array}$ & $\begin{array}{l}\text { Searching a possible } \\
\text { agreement } \\
\text { Promoting conceptual change }\end{array}$ \\
\hline $\begin{array}{l}18-26 \\
\operatorname{Dec}\end{array}$ & $\begin{array}{l}\text { Read the online available paper about peer discussion, conflict and negotiation, } \\
\text { communication strategies, models to analyze the interaction in class. }\end{array}$ & $\begin{array}{l}\text { Reading scientific theories, } \\
\text { acquiring new knowledge and } \\
\text { promoting conceptual change }\end{array}$ \\
\hline $\begin{array}{l}27 \text { Dec } \\
11 \text { Jan }\end{array}$ & $\begin{array}{l}2^{\text {nd }} \text { web forum: within your own group invent a discussion in class about the learning topic of } \\
\text { "digestion". You have imagine a possible conflict between peers oriented to a negotiation, } \\
\text { applying the communication strategies studied. Then make a comment to analyze the } \\
\text { speakers roles, the conflict phases, the outcomes }\end{array}$ & $\begin{array}{l}\text { Searching a possible } \\
\text { agreement } \\
\text { Promoting conceptual change } \\
\text { Applying new achieved } \\
\text { learning }\end{array}$ \\
\hline $\begin{array}{l}12-25 \\
\text { Jan }\end{array}$ & $\begin{array}{l}3^{\text {rd }} \text { web forum: share the works of all the groups. Within your team discuss and compare } \\
\text { analogies and differences. }\end{array}$ & $\begin{array}{l}\text { Peers self-evaluation. Eliciting } \\
\text { self-monitoring. }\end{array}$ \\
\hline $\begin{array}{l}26 \mathrm{Jan} \\
8 \mathrm{Feb}\end{array}$ & $\begin{array}{l}\text { On the base of realized activities and apprehended concepts, in your group create a } \\
\text { discussion in class about the learning topic of "breathing". Then share the final individual } \\
\text { works with the others }\end{array}$ & $\begin{array}{l}\text { Applying new achieved } \\
\text { learning }\end{array}$ \\
\hline 9-19 Feb & $\begin{array}{l}\text { Write a self-assessment on your own activities in the training course. Express an } \\
\text { assessment of the whole Workshop, too. }\end{array}$ & Eliciting self assessment \\
\hline $\begin{array}{l}19-26 \\
\text { Feb }\end{array}$ & $\begin{array}{l}\text { Send a personal dossier to the Faculty composed by written texts of every activity } \\
\text { (exercises, forum interventions, interaction in class invented, individual and collective tak } \\
\text { assessment of the workshop, self-assessment) }\end{array}$ & $\begin{array}{l}\text { Eliciting self assessment and } \\
\text { metacognitive reflection }\end{array}$ \\
\hline
\end{tabular}

Table $\mathrm{n}^{\circ} .1$ : TCW learning design

In the above table (Table $\mathrm{n}^{\circ}$. 1) we showed the online version of TCW. In the in presence version, the discussions in web forum are substituted by face to face interactions. It can be noted that the studied topics (peer discussion, cognitive conflict, negotiation) constitute at the same time the contents and the devices used to learn and interact during the course. First of all the trainer makes known (in the online course) or speaks about (during the in presence lesson) the didactic contract, showing the calendar of activities, the deadlines, the general aim of the course, and the tools that will be used. Then it is asked to the students to introduce themselves filling a presentation form and to recognize their knowledge on concepts such as communication, conflict and negotiation. This introductive moment permits both to traditional and at distance students an immediate direct and active participation, fundamental to engage learners in the training process. In the second activity the students individually read and analyze a short transcription of a part of a real teacherstudent interaction in class. They are invited to express their personal opinions about the management of the interaction. In fact, at the beginning of the course, we assume that the participants usually haven't enough information to do an expert analysis, so that they are supposed to apply their naïve theories. To move to a new conceptualization it is fundamental to show not only other possible visions, but also demonstrating the incorrectness and/or the limits of the old beliefs, creating a desire to search for more satisfying solutions (Posner and al., 1982). To promote this kind of conceptual change the students are asked to discuss in small group (within the forum in online modality, in face to face interaction during the in presence session). The activity consists in finding analogies and differences among the individual works. Peers' discussion is now finalized to distinguish differences, limits and errors of the subjective point of view (Chinn and Brewer, 1993). Moreover while the students do argue their divergent points of view to support their own opinions, they are supposed to work on a new and stronger organization of ideas (Nussbaum and Novick 1982). At this point the students are requested to negotiate a shared file about weaknesses and positive points of the interaction, also proposing strategies to improve it. The students are invited to use both the webforum and a collaborative writing program in the on line version, a discussion in small groups and a written text in the in presence meeting. The trainer then provides a paper dealing with the main topics of the course (activity 4). In the fifth activity the trainees, divided into groups, have to create a discussion about a scholar issue such as "digestion". They have to figure out a possible conflict among peers oriented to a negotiation, applying the studied 
communication strategies. In other word, they have to create a possible negotiation, applying the same strategies in their discussion. In the sixth activity every group can read the works of all groups, finding analogies and differences: a peer-assessment is activated in webforum or through a face to face discussion. The students are involved in a constant process of auto-evaluation of their own and others' work: we think that this active role can be useful to enhance metacognitive processes. At this point every student formulates by himself /herself a new interaction about the curricular theme of "breathing" (activity 7). The participants are then invited to speak about the carried out activities, expressing an assessment on the Workshop and formulating a selfassessment of their own learning process (activity 8). To conclude the curriculum, the students are requested to send a personal dossier (activity 9) composed by written texts of every activity. Collecting and composing a personal dossier is a further strategy offered to students in order to promote considerations and metacognitive attentiveness. It is a way to support a self assessment too. As it can be seen, all the activities are in general structured through a learning-by-doing approach.

\section{TCW online and in presence samples}

The in presence and online TCW participants' characteristics (Tab. $\mathrm{n}^{\circ} .2$ ) are analogue only considering the low presence of men (4\%).

\begin{tabular}{|l|l|l|}
\hline TCW & In presence & Online \\
\hline Number of participants & 112 & 191 \\
\hline Male & $4(4 \%)$ & $7(4 \%)$ \\
\hline Female & $108(96 \%)$ & $182(96 \%)$ \\
\hline Year birth range & $1962-1989$ & $1951-1989$ \\
\hline High school degree & $86(77 \%)$ & $43(23 \%)$ \\
\hline University degree & $28(23 \%)$ & $148(77 \%)$ \\
\hline Full time students & $88(79 \%)$ & $40(21 \%)$ \\
\hline Workers & $24(21 \%)$ & $151(79 \%)$ \\
\hline \multirow{5}{*}{ Geographic origin } & 8 South of Italy $(7 \%)$ & 95 South of Italy $(50 \%)$ \\
\cline { 2 - 3 } & 102 Centre of Italy (91\%) & 88 Centre of Italy (46\%) \\
\cline { 2 - 3 } & 0 North of Italy & 8 North of Italy (4\%) \\
\cline { 2 - 3 } & 2 Foreigners (2\%) & 0 Foreigners \\
\hline
\end{tabular}

Tab. $n^{\circ}$. 2: The characteristics of participants to TCW

Regarding as the year birth range, apparently similar and ample (1962-1989 in presence, 1951-1989 online), we can discover that a great percentage of the in presence participants are younger than the online colleagues: in fact the $41 \%$ was born on 1989 , the $16 \%$ on 1988 . Moreover the $79 \%$ of the in presence participants are full time students with only a high school degree $(77 \%)$, while the same percentage $(77 \%)$ of online students already have a university degree. Furthermore they are frequently employed (79\%), especially in educational institutions.

\section{TCW curricular outcomes}

\begin{tabular}{|l|l|l|}
\hline TCW Final Assessment & In presence: & Online: \\
\hline Excellent & $36(32 \%)$ & $25(13 \%)$ \\
\hline Very good & $26(23 \%)$ & $34(18 \%)$ \\
\hline Good & $31(28 \%)$ & $74(38 \%)$ \\
\hline Average & $15(13 \%)$ & $47(25 \%)$ \\
\hline Sufficient & $4(4 \%)$ & $11(6 \%)$ \\
\hline
\end{tabular}

Tab. $n^{\circ}$. 3: The final assessment of the in presence and online TCW 
In both the modalities of TCW, to assign the final curricular assessment the trainers considered not only the final individual activity (activity 7), but also the participation of the students to the whole training process, also regarding as the role played in the team works and the activity of self-assessment. In TCW the $83 \%$ of the in presence sample reached positive evaluation: the $32 \%$ obtained an excellent judge, the $23 \%$ very good, the $28 \%$ good. We can observe a similar situation in the online course, where $69 \%$ of the sample had a positive judgment. Only few subjects had a low evaluation: the $4 \%$ in the in presence course, the $6 \%$ in the online one (Tab. $n^{\circ} .3$ ).

\section{The Workshop for Observing Children at School (WOCS)}

As teachers are supposed to adopt an expert approach when observing learners at school, thus the WOCS is aimed to learn professional observation methods. The Workshop consists of a system of progressive proposals, both subjective and collective, as the following table show (Table $n^{\circ} .4$ ).

\begin{tabular}{|c|c|c|}
\hline Date & Activity & Aim \\
\hline $\begin{array}{l}17-23 \\
\text { Nov }\end{array}$ & $\begin{array}{l}\text { Fill the presentation form } \\
\text { Publication of didactic contract with list of activities and deadlines. } \\
\text { Write down your idea of "observation". It's not required a scientific definition, we wont know your personal } \\
\text { conception built trough your experience }\end{array}$ & $\begin{array}{l}\text { Eliciting self } \\
\text { explanation } \\
\text { and using } \\
\text { naïve theories }\end{array}$ \\
\hline $\begin{array}{l}24 \mathrm{Nov} \\
3 \mathrm{Dec}\end{array}$ & $\begin{array}{l}\text { Read the short lecture available online about the observation method. Then write down by yourself an } \\
\text { observation text after downloading the videotape available at the url...Publish it }\end{array}$ & $\begin{array}{l}\text { Eliciting self } \\
\text { explanation } \\
\text { and using } \\
\text { naïve theories }\end{array}$ \\
\hline 4-17 Dec & $1^{\text {st }}$ web forum: within your own group find analogies and differences in the individual observational text & $\begin{array}{l}\text { Promoting } \\
\text { conceptual } \\
\text { change }\end{array}$ \\
\hline $\begin{array}{l}18 \mathrm{Dec} \\
2 \mathrm{Jan}\end{array}$ & $\begin{array}{l}2^{\text {st }} \text { web forum: read individually the observation texts done by teacher and educationalist available online. } \\
\text { Then within your own group discuss and negotiate a shared list of positive points and weaknesses about the } \\
\text { analyzed observation texts }\end{array}$ & $\begin{array}{l}\text { Searching a } \\
\text { possible } \\
\text { agreement } \\
\text { Promoting } \\
\text { conceptual } \\
\text { change }\end{array}$ \\
\hline 2- 7 Jan & Read the recommended handbook & $\begin{array}{l}\text { Study of } \\
\text { scientific } \\
\text { theories, } \\
\text { acquiring new } \\
\text { knowledge } \\
\text { and promoting } \\
\text { conceptual } \\
\text { change }\end{array}$ \\
\hline 8-25 Jan & $\begin{array}{l}\text { 8-22 January: } 3^{\text {rd }} \text { web forum: in your own group discuss and negotiate a list of necessary and sufficient } \\
\text { indicators to write the most complete and correct observation text Publish it. } \\
22-25 \text { January: using the shared list like an inventory of evaluation criteria about the quality of observation } \\
\text { text, do by yourself a self-assessment of your first observation text (Activity } 2 \text { ). You have to individuate } \\
\text { weaknesses and strength points of your personal work and eventually suggest changes to improve your } \\
\text { observation text. }\end{array}$ & $\begin{array}{l}\text { Searching a } \\
\text { possible } \\
\text { agreement } \\
\text { Promoting } \\
\text { conceptual } \\
\text { change. } \\
\end{array}$ \\
\hline $\begin{array}{l}26 \mathrm{Jan} \\
8 \mathrm{Feb}\end{array}$ & $\begin{array}{l}\text { Read the list of evaluation indicators provided by teachers and used to assess the quality of observation } \\
\text { texts. On the base of realized activities and apprehended concepts, taking in consideration both the list of } \\
\text { indicators make by yourself an observation text related to videotape available at the url... Publish it }\end{array}$ & $\begin{array}{l}\text { Sharing of } \\
\text { evaluation } \\
\text { criteria with } \\
\text { trainers } \\
\text { Applying new } \\
\text { learning }\end{array}$ \\
\hline $9-22$ Feb & $\begin{array}{l}\text { Sharing of the final observation texts (The folder with all the works done during the last activity is published } \\
\text { and place at whole virtual class disposal) } \\
\text { Express a self-assessment of your whole training course and compare your } 1^{\text {st }} \text { observation text with your last } \\
\text { one using the evaluation criteria shared both with the trainers and the other students. } \\
\text { Write down an assessment of the whole Workshop, too. }\end{array}$ & $\begin{array}{l}\text { Eliciting self } \\
\text { assessment } \\
\text { and } \\
\text { metacognitive } \\
\text { reflection }\end{array}$ \\
\hline $\begin{array}{l}22-28 \\
\text { Feb }\end{array}$ & $\begin{array}{l}\text { Send a personal dossier to the Faculty composed by written texts of every activity (exercises, forum } \\
\text { interventions, observation texts, individual and collective tables, assessment of the workshop, self- } \\
\text { assessment) }\end{array}$ & $\begin{array}{l}\text { Eliciting } \\
\text { metacognitive } \\
\text { reflection }\end{array}$ \\
\hline
\end{tabular}

Tab. $n^{\circ}$. 4: WOCS learning design

The in presence version of the Workshop has the same activities and goals: there are 7 meetings of 2 hours each along two months time. The only difference is the fourth 
activity that is replaced with a lesson, in which the teacher gives the information that the online students can find in the handbook. The interactions in web forum are substituted with discussions face to face. At the beginning of the Workshop the teacher illustrates the didactic contract. Then the trainees are requested to fill a presentation form and to write a short text providing a personal definition of "observation". In the second activity the students have an observation text linked to an online available video (in the in presence Workshop the video is projected). The video reproduces a real school situation recorded by an external observer, in which some children are building a tower in a kinder garden. The video has duration of 60'. The goal of this observation activity is to activate knowledge and competences owned by the students before the study of scientific theories. Then the students discuss in small group about analogies and differences aroused among the individual observation texts (activity 3). At this point there are bases to activate a negotiation of meanings (Scardamalia and Bereiter, 2002). Both in the fourth and in the sixth activity the students work in groups again. In the fourth activity they discuss about a shared analysis of some observation texts. In the sixth they are asked to negotiate a shared list of indicators for child observation, looking for a possible agreement and reaching potential new solutions (Doise and Mugny, 1981; Carugati and Selleri, 2001). The study of the recommended book (activity 5) is now facilitated by the naïve theories recognition and activation. The trainers publish their own list of evaluation criteria. To develop self-assessment process the students have to use the previous list to evaluate the quality of their first observation text. The students are allowed to confront and employ at the same time the two inventories to do the next activity. On the basis of the activities made and apprehended concepts, in the seventh activity the participants have in fact to write a new observation text. The observation activity is linked to another video, similar to the other one; it shows two children collecting a puzzle in an infant school. The $7^{\text {th }}$ activity aims to enable the students to experience the professional practice in the light of the just learned concepts. The eighth and ninth activities are directed to elicit metacognitive processes, asking the students to provide a self-assessment and an assessment of the Workshop (activity 8). Finally they have to compose a personal dossier of every works done during the course (activity 9).

\section{WOCS online and in presence samples}

The composition of the two samples of WOCS are similar in part. Both the online and in presence versions managed during the academic years 2008-2009 have a wide number of participants (143 in presence, 219 online). In both cases the great majority are women, but the in presence course is generally attended by a younger public with respect to the online version. It can be seen that even if the year birth range of the in presence students is apparently ample (1956-1986), the students are mostly born on 1986 (95 subjects or the $65 \%$ of sample), or on 1985 (17 subjects or the $12 \%$ ). In the residual part ( 33 subjects or the $22 \%$ ) only 5 persons are more than 35 years old. In addition, in the online course there are a lot of students already graduated, whereas the Workshop in presence is mainly attended by students with a high school degree. The below table shows the characteristics of the WOCS participants in details (Table $n^{\circ}$. 5): 


\begin{tabular}{|l|l|l|}
\cline { 2 - 3 } \multicolumn{1}{l|}{ WOCS } & In presence & Online \\
\hline Number of participants & 143 & 219 \\
\hline Male & $5(3 \%)$ & $5(2 \%)$ \\
\hline Female & $138(97 \%)$ & $214(98 \%)$ \\
\hline Year birth range & $1956-1986$ & $1960-1986$ \\
\hline High school degree & $17(88 \%)$ & $45(21 \%)$ \\
\hline University degree & $126(12 \%)$ & $174(79 \%)$ \\
\hline Full time students & $119(83 \%)$ & $58(26 \%)$ \\
\hline Workers & $24(17 \%)$ & $161(74 \%)$ \\
\hline \multirow{3}{*}{ Geographic origin } & 16 South of Italy $(11 \%)$ & 125 South of Italy $(57 \%)$ \\
\cline { 2 - 3 } & 127 Centre of Italy $(89 \%)$ & 92 Centre of Italy $(42 \%)$ \\
\cline { 2 - 3 } & 0 North of Italy & 2 North of Italy $(1 \%)$ \\
\cline { 2 - 3 } & 0 Foreigners & 0 Foreign \\
\hline
\end{tabular}

Tab. $\mathrm{n}^{\circ}$ 5: The samples characteristics of WOCS

\section{WOCS curricular outcomes}

The $90 \%$ of the in presence students obtains a very positive evaluation: the $22 \%$ reaches good results, the $29 \%$ very good, the $39 \%$ excellent. The same happens in the online modality: the $91 \%$ of sample obtains very positive judgments. In this case the percentage of excellent assessment is even higher (45\%).

\begin{tabular}{|l|l|l|}
\hline WOCS Final Assessment & In presence: & Online: \\
\hline Excellent & $55(39 \%)$ & $100(45 \%)$ \\
\hline Very good & $42(29 \%)$ & $56(26 \%)$ \\
\hline Good & $32(22 \%)$ & $44(20 \%)$ \\
\hline Average & $11(8 \%)$ & $13(6 \%)$ \\
\hline Sufficient & $3(2 \%)$ & $6(3 \%)$ \\
\hline
\end{tabular}

Tab. $n^{\circ}$. 6: The final assessment of the in presence and online WOCS

\section{Conclusions}

Our work seems to confirm that both in presence and online training can conduct to similar outcomes and achievements. In fact, with regard to the final evaluations in the online course as well as in the in presence one, the percentage of very positive outcomes is relevant. Like we previously explained, the final curricular judgments are obtained taking into consideration not only the quality of the last individual activity (the creation of a peer negotiation in TCW, an observation text in WOCS), but also the participation to the whole training process ${ }^{1}$. With regards to this kind of assessment, an important function was carried out by every student, invited to collect in the final dossier her/his own whole activities. We consider fundamental for the effectiveness of the training to stimulate the students towards a comprehensive reconsideration about their participation and results. In this way learners can autonomously judge themselves.

Another issue can be inferred: the direct intervention of teacher seems to be not so relevant in the training process. In fact, in the online version of the two Workshops, the trainers do not participate explicitly to the activities. They only organize the learning design and offered meaningful activities. Peer interaction and the handbook are the main instruments in every Workshop. Even if in the in presence course the teacher is more active, she doesn't substitute peer interaction, she only supervises the reading of the handbook.

\footnotetext{
${ }^{1}$ The evaluation was conducted by two blind researchers with $93 \%$ of agreement.
} 
As we asked students to produce an evaluation about the Workshop, we can now offer some quotations of self-assessment.

In the first discussion in forum the team work was done without an introduction or a final comment: we don't understand each other because we didn't define how manage our interaction, we didn't provide evidences to support our opinions. There wasn't a real and useful exchange of ideas. I want to note this aspect because in this forum (where we had to read every work to confront our different points of view and to negotiate discursive strategies to improve the analyzed communication) I think it could be fundamental to improve our own discussion to obtain an effective shared solution. In the second webforum the situation developed: we gradually understood that the negotiation is a problem-solving process and the aim of this process is to reach a new and shared result. We participated with care, using the adequate discursive strategies [...]. This training course allowed me to reflect about the importance of a correct manage of communication, and let me actively acquire new knowledge and improve the quality of my general interactions. In fact I applied the new discursive strategies in other situations, also during the daily conversations. Moreover I used peer interaction to organize the classes in my apprenticeship in primary school.

This TCW student shows to understand the causes of weaknesses of her work: the shortage of opinions exchanged and the incorrect conversation management. There is a double activation of critical spirit, directed both to herself and to the organization of the team work. She underlines the relevance of a correct application of learnt concepts about communication in different kinds of interaction, in professional work as well as in daily life.

After the study of the handbook, we discussed about possible useful indicators to make a correct observation. [...] Using the criteria provided by the teachers and our criteria too, we could self-evaluate our first observation text, individuating limits and strengthens. To analyze my activities let my awareness to grow. The confront with trainers evaluation criteria, gave me a confirmation about the effectiveness of my achievements. In my opinion I acquired a critical and expert look to observe that will allow me to do my work as teacher in a competent way.

In the last extract the participant of WOCS talks about the importance of an active participation to the knowledge building process. The elicitation of a constant selfmonitoring permitted a growth of awareness about the information acquired, consenting a significant learning.

\section{References}

Bennet, R.E. (1998). 'Reinventing assessment: speculations on the future of large-scale educational testing service' Princeton NJ, Policy Information Center.

Bion, W.R. (1961). 'Experiences in Groups', London, Tavistock.

Bruner, J.S. (1990). 'Acts of Meaning', Cambridge, MA, Harvard University Press

Chi, M. T. H., de Leeuw, N., Chiu, M. H. and LaVancher, C. (1994). 'Eliciting self-explanations improves understanding', Cognitive Science, 18 (3), pp. 439-477.

Cunningham, D. (1992). 'Assessing constructions and constructing assessments: a dialogue', in T. M. Duffy and D. H. Jonassen, eds, 'Constructivism and the Technology of Instruction', Hillsdale, NJ, Lawrence Erlbaum Associates Inc. pp. 35-44.

Doise, W. and Mugny, G. (1981). 'Le développement social de l'intelligence', Paris, Interéditions.

Doise, W., Mugny, G. and Pérez, J.A. (1998). 'The social construction of knowledge: Social marking and socio-cognitive conflict', in U. Flick. (Ed.), 'The psychology of the social', Cambridge, Cambridge University Press, pp. 77-90.

Duffy, T. M., and Cunningham, D. J. (1996). 'Constructivism: Implications for the design and delivery of instruction', in D. H. Jonassen, ed, 'Handbook of Research for Educational Communications and Technology’, New York, Simon \& Shuster Macmillan, pp. 170-198. 
Farr, R.M., and Moscovici, S. (Eds.). (1984). 'Social Representations'. Cambridge, Cambridge University Press.

Gardner, H. (1991). 'The unschooled mind. How children think and how schools should teach', New York, Basic Books

Gee, J.P. and Green, J.L. (1998). 'Discourse analysis, learning, and social practice: A methodological study', 'Review of Research in Education, 23, pp. 119-169.

Jonassen, D. H. (1992a). 'Objectivism versus constructivism: Do we need a new philosophical paradigm?' Educational Technology Research and Development, 39(3), pp. 5-14.

Jonassen, D. H. (1992b). 'Evaluating constructivist learning', in T. M. Duffy, and D. H. Jonassen, ed, 'Constructivism and the technology of instruction', Hillsdale, NJ, Lawrence Erlbaum Associates Inc., pp. 137-148.

Knowles, M. S. (1973). 'The adult learner, a neglected species', Houston, Gulf Publishing Co.

Kuhn, T. S. (1996). 'The structure of scientific revolutions', Chicago, The University of Chicago Press.

Lake, C. and Tessmer, M. (1997). 'Constructivism's implications for formative evaluation', Proceedings of annual meeting of the Association for Educational Communications and Technology, Albuquerque, New Mexico.

Lakoff, G. (1987). 'Women fire and dangerous things', Chicago, University of Chicago Press.

Lapadat, J.C. (2000). 'Construction of science knowledge: Scaffolding conceptual change through discourse', Journal of Classroom Interaction, 35 (2), pp. 1-14.

Lesh, R and Doerr, H. (2003). 'Beyond constructivism', London, Lea.

Mason, L. (2001). 'Introducing talking and writing for conceptual change: a classroom study', Learning and Instruction, 11, pp. 305-329.

Moore, G.M. (1989). 'Three types of interaction', American Journal of Distance Education, 3 (2).

Moroni, C, Smestad, O. and Kinshuk, K. (2006). 'Improving discursive negotiation in web discussion forum', in Kinshuk, Demetrios, G., Sampson, J., Spector, M. and Isaìas, P. (Eds.). (2006). Proceedings of $3^{\text {rd }}$ International Conference on Cognition and Exploratory Learning in Digital Age, Barcelona, Spain.

Nicolini, P., Lapucci, T. and Moroni, C. (2007). 'Is it possible to train professional skills online? Teaching- learning strategies to improve practices change in online learning', in Lionarakis, A. (Ed.). 'Forms of Democracy in Education: Open Access and Distance Education. Proceedings of $4^{\text {th }}$ International Conference on Open Distance Learning, vol. A, Researches - Athens, Greece, pp. 206-212.

Nicolini, P., Moroni, C., Lapucci, T. and Kinshuk, K. (2007). 'Teaching-Learning online strategies: conceptual change and negotiation', in Kinshuk, Demetrios, G., Sampson, J., Spector, M. and Isaìas, P. (Eds.). (2007). Proceedings of $4^{\text {th }}$ International Conference Cognition and Exploratory Learning in Digital Age- Carvoeiro, Portugal, pp. 85-92.

Nicolini, P., Lapucci, T. and Moroni, C. (2008). 'Self assessment: a crucial process in e-training', in Kinshuk, Demetrios, G., Sampson, J., Spector, M., Isaìas, P., Ifenthaler D. (Eds.). (2008). Proceedings of $5^{\text {th }}$ International Conference Cognition and Exploratory Learning in Digital Age - Freiburg, Germany, pp. 253-260.

Nicolini, P., Lapucci, T. and Moroni, C. (2008). 'The role of cognitive conflict and peer interaction in conceptual change: a course on child observation practices', Gestalt Theory, 30 (4), pp. 447454.

Pear, J. J., and Crone-Todd, D. E. (2002). 'A social constructivist approach to computer mediated instruction', Computers \& Education, 38, pp. 221-231.

Perkins, D. N. (1992). 'What constructivism demands of the learners', in T. M. Duffy and D. H. Jonassen, ed, 'Constructivism and the technology of instruction', Hillsdale, NJ, Lawrence Erlbaum Associates Inc., pp. 161-166.

Piaget, J. (1970). 'Genetic epistemology.', New York, Columbia University Press.

Pine, K. J. \& Messer, D., J., (2000). 'The Effect of Explaining Another's Actions on Children's Implicit Theories of Balance', Cognition and Instruction, 18 (1), pp. 35-51.

Pontecorvo, C. (1993). 'Forms of discourse and shared thinking', Cognition and Instruction, 11 (3-4), pp. $189-196$.

Posner, G. J. (1995). 'Analyzing the curriculum' New York, McGraw-Hill Inc.

Rafaeli, S., Barak, M., Dan-Gur, Y. \& Toch, E (2003). Knowledge sharing and online assessment. Proceedings Online of IADIS 2003: http://www.iadis.net

Rafaeli, S.and Tractinsky, N. (1989). 'Computerized tests and time: measuring, limiting and providing visual cues for time in computerized tests' Behavior and information technology, 8, (5), pp. $335-353$.

Rafaeli, S. and Tractinsky, N. (1991). 'Time in Computerized Tests: A multi-trait Multi-method Investigation of General Knowledge and Mathematical Reasoning in Online Examinations', Computers in Human Behavior, 7, (2), pp. 123-142. 
Resnick, L. B. and al. (1993). 'Reasoning in conversation', Cognition and Instruction, 11 (3-4), pp. 347-364.

Scardamalia, M. and Bereiter, C. (1996). Engaging students in a knowledge society. Educational leadership, 54 (3), pp. 6-10.

Scardamalia, M. and Bereiter, C. (2002). Knowledge building. In Deighton L. C. (Ed). Encyclopedia of education. Macmillan Reference.

Scriven, M. (1983). 'Evaluation models: Viewpoints on educational and human services evaluation', Boston, Kluwer-Nijhoff.

Sternberg, R. (1997). 'Thinking styles', Boston, Cambridge University Press.

Vrasidas, C. (2000). 'Constructivism versus objectivism: Implications for interaction, course design, and evaluation in distance education', International Journal of Educational Telecommunications, 6(4), pp. 339-362. 